\title{
MANAGEMENT OF EDUCATIONAL PROCESS IN SOCIAL SCHOOLS OF FRANCE
}

\section{Yashchuk Serhii ${ }^{1}$}

DOI: https://doi.org/10.30525/978-9934-571-89-3_39

The Regional Aquatory Institute for Social Work (IRTS) has its own peculiarities in the management of the educational process. The administrative structure of the social school has such form: functional organization of educational activities (responsible for the training center; office assistants); elementary education (headmaster of the department, kindergartener, social service assistant, science advisor, specialized teacher, pedagogue) [1, p. 334]; technology of social and well-known interference; specialized technical education; Moodle platform (educational manager; auxiliary teams; certification department); higher and permanent education (department manager; personal services sector); Department of Social Economics (head of social economy; assistants); Department of Family Assistance (manager of the department; teachers of social preparation); permanent seminars (specialized master; short training - administration management); service of development the permanent education (preparatory department - third level listeners, Quiz Department about student's satisfaction with learning organization; coordination department); International department (Economics and Financial Department, Competency Evaluation Department, Erasmus + Department, Research and Animation Department, IT and Multimedia Department); Innovative Professional Development (pedagogical representative bodies; promotion commission; technical and pedagogical committees; manager committees); administrative resources (reception; lost and found office; information office); accounting service; school service (registration department: student card; reader card; scholarship card; certificate of education; certificate of registration; membership in social security of students; change coordinates for students); security; restaurant application [5].

\footnotetext{
${ }^{1}$ National University of Life and Environmental Sciences, Ukraine
} 
The management structure [3, p. 22] of the educational resources in the social school IRTS has such forms: educational project; coach to be responsible for further training; curriculum; individual training course; training group; pedagogical questions; pedagogical assistant in education; certification of participants; documentary center; works, reviews, advice on memoirs; loans; duplicator.

Access to educational services is through e. campus [4, p. 14]. The site is available to students and trainees during the whole course. The access to the site is carried out by the user's name: the name, password -4 student card digits. On this site students and trainees find their curriculum, administrative documents, methodological and teaching materials and other practical information. The manager has access to the multimedia room of the social school. Access to the multimedia room is open from Monday to Friday from 8:15 till 17:00, and till 16:30 - on Friday. IRTS multimedia room has 15 work places, connected to the Internet and protected by antivirus. WIFI Zone in IRTS: there are classes on the ground floor and in the corridors. The connection is made by the student and trainee selecting the WIFI network "IRTS_visiteurs" from the terminal (smartphone or laptop). Students or trainees need to register and send a valid email address and they will receive an email and password (which is automatically provided through the portal) to this email address, which will have to be updated within 10 minutes.

Let's pay attention to the management structure of IRTS "representation and the right to express opinions" [2, p. 21]. This structure has a career progression. The purpose of this international commission is a leadership and directly exchange between students and the IRTS on various topics from the beginning of training. It is not just pedagogical difficulties, but also offers that go beyond the scope of the curriculum: practical life, renewal and use of resources, general organization, information about students, etc. However, during direct communication with the leadership, pedagogical disciplines can be mentioned in cases where all problems have not been solved before, at the meeting with the educational manager.

The IRTS management structure "representation and the right to express opinions" includes the so-called animated director, who communicates directly with the delegates from the students. Two representatives who are selected among the students take initial training: motivation training. Delegates play the role of representation at meetings. To do this, they collect questions or suggestions, attend meetings and inform them about their advancement of responses or provide information from management. They also ask to attend disciplinary committees. Delegates' election is conducted from the beginning of the school year and is organized by the responsible person for studying. Meetings are held 6 times a year, and occur on Wednesdays at 15:30. Conventions and reports are available at e.campus and are sent by post to the vice director of the IRTS governance structure "Representation and the right to express opinions" [5].

Consequently, the Statute of the Regional Association and IRTS Social Work provides the representation of students, trainees and pupils in the process of the educational management. Representatives are appointed or elected from delegates as well as among them. Elections or appointments are made by the responsible person 
for training. Students, listeners and pupils through their representatives may: express their difficulties or issues of a general nature; offer suggestions; to participate by voting. Representative names in different instances will be available at e.campus as soon as they are selected.

The security department is involved in security and fire safety. The floor plan is available in the audience hall. Signs, placed on the walls of the building help to find the way out of the building. Details are in the IRTS lobby and indicate the location of the offices and rooms, with their numbering. Details are in the IRTS lobby and indicate the location of the offices and rooms with their numbering. In case of an accident that will make danger to people' health and safety, it is possible to inform the IRTS staff as soon as possible. Rescuers will be able to intervene immediately. A list of rescuers with specified office and telephone numbers is located on the wall in the lobby. The establishment also has 3 defibrillators. Evacuation plans and safety instructions are located in the main hall and at all evacuation points. The collection point is located behind the building at the parking near the document center. In the case of siren, the safety instructions are given below: keep calm; close doors and windows and evacuate closer to the safe exit to get to the meeting place with the rescuers; do not come back and do not wait when the signal will appear again; spend your time reading and learning the basic instructions; evacuation training can take place at any time [5].

IRTS has rules for using a document center, a multimedia room, e.campus e.learning. It is a common life where you need to follow some rules. IRTS has a history, values, identity. This is an institution, where people work and study. The rules of conduct are based on a simple idea: to take care of another person, to create conditions for safe living. Article 1 of the rules of using IRTS is a regulations. This Regulation is formed according to the provisions of Articles L6352-3 and L.6352-4 and R6352-1 to R6352-15 of the Labor Code in France. It applies to all students, trainees and pupils, who are registered in IRTS, that is, a person who has complied with all administrative formalities concerning the conditions of access and registration in the cycle or training. This provision is also intended for everyone present in the room. Article 2 of the rules of using IRTS is a curriculum. The training program clearly includes goals, organization of training, teaching methods, assessment methods and certification tests. The program is sent with the applicable rules to each hearer or provided on an e-campus for students or pupils while entering the course. Article 3 of the rules of using IRTS - access to placements. Students, trainees or pupils must correspond the IRTS working hours and operational procedures, and be sure to take care of the provided teaching materials. Article 4 of the IRTS usage rules - attendances and certification. Obligatory participation in training events according to established schedules. A student, trainee or a pupil is required to sign the attendance reports that are provided to him in order to be deprived of disciplinary sanctions. Any absence should be justified [1, p. 335]. Absence is considered justified on the basis of official documentary confirmation for a maximum of 15 days: medical examinations, illnesses, accidents at work; holiday for family events. Reminding for students in the employment situation: during the 
training hours the employer can't provide the work. This is not considered to be a justifiable absence. Internship time is defined as the training time at the institution or service that is mandatory with the conclusion of the IRTS agreement. A visit certificate is issued to a person who fulfilled the terms of the visit, and is indicated in a cycle or program, in accordance with the training program.

\section{References:}

1. Yashchuk S. P. Formuvannja profesijno-pravovoji kompetentnosti studentiv. Naukovyj visnyk Nacionaljnogho universytetu bioresursiv i pryrodokorystuvannja Ukrajiny. Ser.: Pedaghoghika, psykhologhija, filosofija. 2016. № 253. S. 333-339.

2. Yashchuk S. P. Konstytucyonnoe y mezhdunarodnoe pravo: sovershenstvovanye osnovnogho zakona. Suchasni naprjamy teoretychnykh i prykladnykh doslidzhenj: materialy mizhnar. nauk.prakt. konf. (Odesa, 20-31 berez. 2012 r.). Odesa, 2012. T. 18. S. 21-22.

3. Zhuravska N.S. Metodyka navchannja ta vykhovannja u vyshhykh navchaljnykh zakladakh krajin Jevropejsjkogho Sojuzu ta Ukrajiny. Porivnjaljnyj aspekt: monoghr. Nizhyn: PP Lysenko MM., 2015. $608 \mathrm{~s}$.

4. Zhuravska N.S. Teorija i metodyka profesijnogho navchannja: navch.-metod. posib. Kyjiv: Vydavnychyj centr NAU, 2006. $66 \mathrm{~s}$.

5. l'IRTS [Electronic resourse]. - Mode of access : http://www.campus-irts.fr 